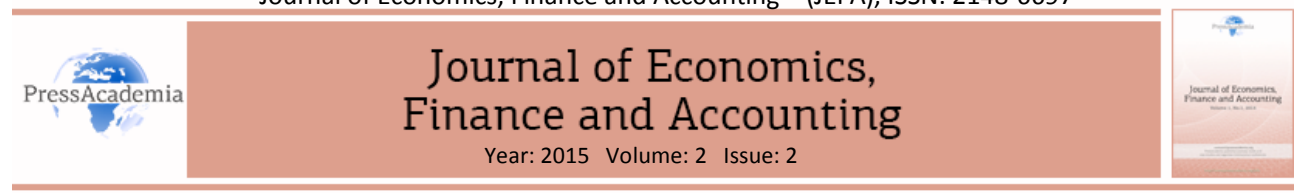

\title{
CORPORATE SUSTAINABILITY REPORTING AND SITUATION IN TURKEY
}

\section{DOI: 10.17261/Pressacademnia.2015211515}

\author{
Saime Once', Ahmet Onay², Gul Yesilcelebi ${ }^{3}$ \\ ${ }^{1}$ Anadolu University. sonce@anadolu.edu.tr \\ ${ }^{2}$ Anadolu University. ahmet onay@anadolu.edu.tr \\ ${ }^{3}$ Gümüşhane University. gyesilcelebi@hotmail.com
}

\section{Keywords}

Corporate sustainability, corporate sustainability reporting, global reporting Initiative (GRI).

\begin{abstract}
The need to provide stakeholders with the information whether the corporate sustainability obligations imposed on business have been met or not, necessitated environmental and social data to be reported and presented alongside financial information relating to operating activities. This study puts forth conceptual explanations related to sustainability, and sustainability reporting framework for sustainability reporting, organizations and indexes, and then reveals the sustainability reporting situation in Turkey. To this end, in line with data in the corporate sustainability portal as of May 2015, corporate sustainability reports in Turkey were analysed. According to the data obtained from this portal, a total of 181 corporate sustainability reports were published by 72 organizations in Turkey between the years 2005-2014. 130 of these reports were based on the GRI reporting guidelines.This study on corporate sustainability reporting contains 26 benchmarks related to organizations issuing reports and the reports themselves. In this study, sector distribution of the organizations issuing corporate sustainability reports, their sizes, publicity, availability on the stock market, the number of employees, turnover, GRI OS (Global Reporting Initiative - Organizational Stakeholders) membership, UNGC (United Nations Global Compact) membership and types of issued corporate sustainability reports, the release years, the reporting periods, the report language, GRI application levels, GRI application statements, reference, auditing, audit providers, industry attachment, stakeholder panel/expert opinion have been identified as the criteria.
\end{abstract}

\section{KURUMSAL SÜRDÜRÜLEBILIRLIK RAPORLAMASI VE TÜRKIYE'DEKI DURUM}

\section{Anahtar Kelimeler}

Kurumsal

SürdürülebilirlikKurumsal

Sürdürülebilirlik

Raporlaması, Küresel

Raporlama Girişimi (Global

Reporting Initiative - GRI)

\section{ÖZET}

Kurumsal sürdürülebilirliğin işletmelere yüklediği sorumlulukların yerine getirilip getirilmemesine ilişkin bilginin paydaşlara ulaştırılması ihtiyacı, işletme faaliyetlerine ilişkin finansal bilgilerin yanında çevresel ve sosyal verilerin de raporlanması ve sunulmasını gerektirmiştir. Bu çalışmada sürdürülebilirlikle ilişkili kavramsal açıklamalara, sürdürülebilirlik ve sürdürülebilirlik raporlaması ile ilgili raporlama çerçevelerine, kuruluşlara ve endekslere yer verilmiş, sonrasında sürdürülebilirlik raporlamasının Türkiye'deki durumu ortaya konmuştur. Bu amaçla 2015 Mayıs ayı itibariyle kurumsal sürdürülebilirlik portalında (www.kurumsalsurdurulebilirlik.com) yer alan veriler doğrultusunda Türkiye'deki kurumsal sürdürülebilirlik raporları incelenmiştir. Bu portaldan elde edilen verilere göre Türkiye' de 2005-2014 yılları arasında 72 kuruluş tarafından toplam 181 kurumsal sürdürülebilirlik raporu yayınlanmıştır. Bu raporların 130'u GRI raporlama rehberini temel almıştır. Kurumsal sürdürülebilirlik raporlaması üzerine yapılan bu çalışmada, rapor yayınlayan kuruluşlar ve raporlarla ilgili olmak üzere 26 adet ölçüte yer verilmiştir. Çalışmada kurumsal sürdürülebilirlik raporu yayınlayan kuruluşların sektör dağılımı, büyüklükleri, halka açıklık, borsada işlem görme, çalışan sayısı, ciro, GRI OS (Global Reporting Initiative - Organizational Stakeholders) üyeliği, UNGC (United Nations Global Compact) üyeliği ve yayınlanan kurumsal sürdürülebilirlik raporlarının türü, yayınlanma yılları, raporlama dönemi, rapor dili, GRI uygulama düzeyi, GRI uygulama beyanı, referans, bağımsız denetimden geçme, denetim sağlayıcısı, sektör eklentisi, paydaş paneli/uzman görüşü ölçüt olarak belirlenmiştir. 


\section{GiRiş}

Sanayi Devriminden sonra giderek artan tahribatlar, özellikle 20. yüzyıldan itibaren dünya kamuoyunun dikkatini çekmiş ve çözümler aranmaya başlanmıştır. Giderek daha da artan dünya nüfusunun ihtiyaçlarının karşılanması anlamına gelen toplumsal refahı artırmak için tahrip edilen ekonomik, çevresel ve sosyal kaynaklara duyulan daha şiddetli ihtiyaç, toplumun ihtiyaçları giderilirken bu kaynakların korunması ve fütursuzca tüketilmemesi gerektiği düşüncesini ortaya çıkarmıştır. Buna göre, kısa dönemli ihtiyaçların karşılanması veya ekonomik kazanımlar için uzun dönemde hatta sonsuza kadar ihtiyaç duyulacak kaynaklar feda edilemez; yani sadece sürekli ve dengeli bir gelişim kabul edilebilir. Bu düşünce daha önceden de çeşitli toplantılarda, raporlarda ve konferanslarda tartışılmış olsa da, ilk defa sürdürülebilir kalkınma ifadesiyle 1972 yılında Stockholm'de yapılan Birleşmiş Milletler İnsan Çevresi Konferansında kavramlaştırılmış ve Birleşmiş Milletler Çevre ve Kalkınma Komisyonu tarafından yayınlanan ekonomik, çevresel ve sosyal sorunlara küresel çözümler üretmeye çalışan Ortak Geleceğimiz Raporunda, literatürde en çok kullanılan ve kabul edilen şekliyle tanımlanmıştır. Bu tanıma göre, sürdürülebilir kalkınma; 'gelecek nesillerin ihtiyaçlarını karşılayabilme yeteneğini ortadan kaldırmaksızın günümüz neslinin ihtiyaçlarının karşılanabilmesi' dir. Ortak Geleceğimiz Raporu, sürdürülebilir kalkınmayı kaynaklarının tüketiminin, yatırım kararlarının, teknolojik gelişmenin ve kurumsal değişimin bir uyum içinde gerçekleştiği ve insan ihtiyaçları ile isteklerinin şimdi ve gelecekte karşılanabilme potansiyelinin artırıldığı bir değişim süreci olarak ele almaktadır (Dünya Çevre ve Kalkınma Komisyonu, 1987: 43).

Sürdürülebilirlik kavramını makro açıdan ele alan sürdürülebilir kalkınma tanımı şimdiki neslin ihtiyaçlarının giderilmesi ile gelecek nesillerin ihtiyaçlarını karşılayabilme yeteneğine zarar verilmemesi dengesinin doğru kurulmasına, yani insanlığın devamlılığına odaklanmıştır. Ekonomik sisteme, genel olarak iş gücü piyasası ile müşterilerden oluşan insan faktörüne ve ekosisteme zarar verilmeden yeryüzünün ve insanlığın devamlılı̆̆ının sağlanması makro anlamda temel düsturdur.

Sürdürülebilir kalkınma kavramı, mikro bakış açısıyla ele alındığında ise küresel sürdürülebilir kalkınmanın sağlanması için ülke ekonomilerinin, dolayısıyla işletmelerin sürdürülebilir biçimde kalkınması gerektiği anlaşılır. Bir araya gelerek ülke ekonomilerini oluşturan işletmeler, sürdürülebilir kalkınmaya ekonomik, çevresel ve sosyal kaynaklara zarar vermeyerek katkı sağlayabilir. Bu bakış açısına göre, işletmelerin gelir elde etme, karlııı gibi finansal sorumluluklarının yanında yeni sorumlulukları da doğmuştur. İşletmelerin bu yeni sorumluluklarını ifade eden ve sürdürülebilir kalkınma amaçlarına işletme bakış açısıyla yaklaşan kavram kurumsal sürdürülebilirliktir.

Kurumsal sürdürülebilirliğin işletmelere yüklediği yeni sorumlulukların yerine getirilip getirilmemesine ilişkin bilginin paydaşlara ulaştırılması ihtiyacı, işletme faaliyetlerine ilişkin finansal bilgilerin yanında çevresel ve sosyal verilerin de raporlanması ve sunulmasını gerektirmiştir. Sürdürülebilir kalkınma hedefine odaklanan kurumsal sürdürülebilirliğin ölçülmesi, işletmelerin sürdürülebilirlik faaliyetlerine yönelik açıklamalar yapması ihtiyacını ortaya çıkarmıştır. Bu ihtiyaç, sürdürülebilirlik raporlamasını doğurmuştur. Sürdürülebilirlik raporlaması ortaya çıktığından bu yana, kar amacı gütmeyen küresel organizasyonlar ve inisiyatifler raporlamanın nasıl yapılacağı noktasında işletmeleri yönlendiren rehberler, ilkeler ve standartlar oluşturmuştur ve oluşturmaya devam etmektedir. 
Çalışmamızda kurumsal sürdürülebilirlik kavramı ve onun arka planındaki temel kavram olan sürdürülebilir kalkınmanın gelişimine yer verilmiş, sonrasında bu iki kavramın ortaya çıkmasıyla raporlama anlayışındaki değişimle beraber ihtiyacı giderek artan kurumsal sürdürülebilirlik raporlaması açıklanmıştır. Daha sonra Dünya'da kurumsal sürdürülebilirlik raporlamasına yön veren kuruluşlar ve raporlama çerçeveleri genel hatlarıyla ifade edilmiştir. Bu kavramsal açıklamalar sonrasında kurumsal sürdürülebilirlik raporlamasının Türkiye'de ne durumda olduğu ortaya konulmuştur.

\section{SÜRDÜRÜLEBILIR KALKINMA}

18. yüzyılda İngiltere'de ortaya çıkan ve sonrasında bütün dünyayı etkileyen Sanayi Devrimi, bilimsel gelişmeler sonucunda icat edilen buharlı makinelerin, kol gücüne dayalı üretim tarzını makine gücüne dayalı üretim tarzına dönüştürmesiyle makineleşmiş endüstrinin doğmasına yol açmıştır. Sanayi ve tarımda makinelerin kullanılmaya başlamasıyla üretim artışı ve bunun sonucunda mal bolluğu yaşandığı için artan dünya nüfusunun ihtiyaçları çok daha kolay karşılanmaya başlanmış, yani refah artışı yaşanmıştır. Diğer taraftan Sanayi Devriminin ortaya çıkardığı artan üretim kapasitesi ekonomik, çevresel ve sosyal kaynakların acımasızca tüketilmesine yol açmıştır. Sanayileşme bunca nimetin yanında o dönemde ilk aşamada farkına varılamayan ve etkileri günümüzde de görülen birçok sorunu da beraberinde getirmiştir. Sanayi devrimi ile beraber ortaya çıkan işçi sınıfına sunulan kötü çalışma koşulları, zorla çalıştırma, düşük ücretler, çocuk işçi çalıştırılması ve doğal çevrenin göz ardı edilmesiyle ortaya çıkan su kaynaklarının yok edilmesi, hava kirliliği, çölleşme, iklim değişikliği, küresel ısınma ilk akla gelen örneklerdir.

Özellikle sosyal ve çevresel kaynaklarda yapılan tahribat kamuoyunun dikkatini daha fazla çekmiştir. İşçilerin sağlıksız koşullarda çalıştırılması, haklarının kısıtlanması, fazla ve zorla çalıştırma, su kaynaklarının kirletilmesi, küresel ısınma, hava kirliliği gibi sorunlar günümüzde de tartışılmaktadır. Bu sorunların ortaya çıkması sadece milli gelirde ve refah seviyesinde yaşanan artışla kalkınma sağlanamayacağını, kaynakların verimli bir şekilde kullanılması ve doğaya, ekonomiye ve sosyal faktörlere zarar verilmemesi gerektiğini göstermiştir. Bu sorunlara çözümler üretme çabaları sonucunda kalkınma anlayışı değişmiş ve sürdürülebilir kalkınma kavramı ortaya çıkmıştır.

Sürdürülebilir kalkınmanın en yaygın kullanılan ve kabul gören tanımı Bruntland Raporu olarak da bilinen Birleşmiş Milletler Ortak Geleceğimiz Raporundaki tanımıdır. Tanımın ortaya çıkmasını sağlayan amaç, gelecek nesillerin refahının korunması gerektiğidir. Bu refahın sağlanabilmesi için gelecek nesillerin gelir yaratabilme gücü korunmalıdır; bunun için de gelir yaratmak için kullanılması gereken ekonomik, çevresel ve sosyal sermaye sınırlı ve dengeli olarak tüketilmelidir.

Aşağıda vurgulanan öncelikler sürdürülebilir kalkınma kavramını tamamlar ve daha iyi anlaşılmasını sağlar (Fischer, Steimle ve Zink, 2008: 5):

- Sürdürülebilir kalkınma, insanlığın ihtiyaçlarına odaklanmıştır ve sadece çevresel sorunlara karşı çözüm aramaz. Rio Deklarasyonu'nun birinci maddesine göre sürdürülebilir kalkınma endişelerinin merkezinde insanlık yer alır. İnsanlık, çevre ile dengelenen sağlıklı ve üretken bir yaşam sürme hakkına sahiptir.

- Bruntland Raporunda bulunan sürdürülebilir kalkınma tanımı, nesiller arasında ve içinde eşitlik fikrine odaklanmıştır; her nesil önceki neslin mirasından 
faydalanabilmelidir ve gelecek nesillerin ihtiyaçlarının karşılanmasını garanti altında tutmaya mecburdur.

- Sürdürülebilir kalkınmanın üç temel taşı olarak adlandırılan ekonomik, çevresel ve sosyal amaçlar eşit şekilde dikkate alınmalıdır.

Sürdürülebilirlik kapsamındaki tartışmalar, sürdürülebilir kalkınma zeminindeki üç ilkeyi kaynaştırmıştır. Bu ilkeler; ekonomik refah, çevresel bütünlük ve sosyal eşitliktir. Bu ilkelerden her biri gereklidir ancak tek başına yeterli değildir. Eğer bu prensiplerden bir tanesi desteklenemez ise, kalkınma sürdürülemeyecektir (Bansal, 2005: 198):

- Ekonomik Refah: Ekonomik refah ilkesi, toplum içinde yer alan organizasyonların ve bireylerin üretim kapasitesi sayesinde makul bir yaşam seviyesine sahip olmasını destekler. Ekonomik refah, malların ve hizmetlerin bütün dünyada yaşam standartlarını artıracak şekilde üretilmesi ve sunulmasını içerir. Ekonomik refah, doğal olarak sosyal eşitliğe ve çevresel bütünlüğe bağlıdır. Ekonomik refaha ulaşamayan bir toplum kendi sağlığını ve mutluluğunu tehlikeye atar, gelire ilişkin faydalara eşit şekilde erişememe insanlar arasında çatışmaya yol açar.

- Çevresel Bütünlük: Çevresel bütünlük ilkesi, yer kürenin toprak, hava ve su kaynaklarının insani faaliyetlerle sömürülmemesini garantiye almaktadır. Ekosistem sınırlı yenilenebilme ve taşıma kapasitesine sahiptir. Artan nüfus, aşırı tüketim, hava kirliliğinin artması ve doğal kaynakların yok edilmesi çevresel bütünlüğü tehdit etmektedir. Biyolojik çeşitliliğin azalması, ozon tabakasının incelmesi, sera gazı salınımı, hatalı atık yönetimi, zehirli sızıntılar, orman açma ve ağaçlara zarar verme bunlarla sınırlı olmamakla beraber doğal çevre üzerinde negatif etkisi olan insani faaliyetlere örnektir. Eğer doğal çevre riske edilirse; hava, su ve gıda gibi insan yaşamının temel ve gerekli kaynakları da risk altında olacaktır.

- Sosyal Eşitlik: Sosyal eşitlik ilkesi, toplumun her ferdinin kaynaklara ve fırsatlara eşit erişimini garanti altına alır. Sürdürülebilir kalkınma tanımının merkezinde ihtiyaçların günümüzde ve gelecekte giderilmesi gerekliliği yer alır. İnsani ihtiyaçlar sadece gıda, giyinme ve barınma gibi temel ihtiyaçlardan değil; sağlık, eğitim ve politik özgürlük gibi iyi standartlarda yaşam sürmeyi sağlayan ihtiyaçlardan da oluşmaktadır.

\section{KURUMSAL SÜRDÜRÜLEBILIRLIK}

İşletme yönetiminin teori ve uygulamada temel tartışma konularından birisi işletmelerin sorumluluk alanlarıdır. Milton Friedman'dan (1962) bu yana, özellikle son yıllarda bu konuda uzlaşıldığı söylenebilir. İşletmelerin sadece müşteri ve hissedarlarını değil, faaliyetlerinden etkilenen ve bu faaliyetleri etkileyen bütün kesimleri sorumluluk alanlarına dahil etmeleri gerektiğini tavsiye eden veya zorunlu gören anlayışlar giderek yaygınlaşmaktadır. Bu bakış açısına göre, şirketler finansal amaçlarına ulaşmak için çaba gösterirken ortaya çıkan ekonomik, çevresel ve sosyal sonuçlardan da sorumlu olmalıdırlar (Tokgöz ve Önce, 2009: 251). Bu sorumluluklar dikkate alınarak, sürdürülebilir kalkınma amacına ulaşmak için ekonomik sistemin içinde yer alan işletmelerin sürdürülebilirliği sağlanmalıdır.

Küresel çerçevede sürdürülebilir kalkınmanın nihai amacı, insanlığın ihtiyaçlarının sürekli olarak giderilmesidir. Bu düşünceyi işletme seviyesine dönüştürdüğümüzde, kurumsal 
sürdürülebilirlik işletmenin gelecekte paydaşlarının ihtiyaçlarını karşılama kabiliyetini riske atmadan şimdiki direkt ve endirekt paydaşlarının (hissedarlar, çalışanlar, müşteriler, baskı grupları, kuruluşlar gibi) ihtiyaçlarının karşılanması olarak tanımlanabilir. Bu hedef doğrultusunda firmalar ekonomik, çevresel ve sosyal sermaye tabanlarını korumalı ve genişletmelidirler (Dyllick ve Hockerts, 2002: 131).

Kurumsal sürdürülebilirlik tanımı kurumsal sürdürülebilirlik perspektifinden dolaylı olarak işletmenin sosyal sistemdeki rolünün anlaşılmasını sağlayan birçok varsayımı kapsamaktadır (Fischer, Steimle ve Zink, 2008: 7-8) :

- Insanların ihtiyaçlarını karşılamak, işletme faaliyetlerinin amacıdır ve her işletmenin var oluş sebebidir. Bu nokta, genel olarak sürdürülebilir kalkınma tanımı ile işletme seviyesindeki uygun faaliyetler arasında güçlü bir ilişki olduğuna işaret eder. İşletmeler sürdürülebilir kalkınma yolunda önemli aktörlerdir. Sadece insanların ihtiyaçlarının giderilmesinde değil, ihtiyaçların yaratılmasında ve böylece tüketim kalıplarının ve yaşam tarzlarının etkilenmesinde de belirleyicidirler. Bu durum sürdürülebilir kalkınma için yeterli stratejilerin belirlenmesinde kritiktir.

- Ekonomik sistem, işletmenin sürekliliği ilkesinin geniş bir anlayışı olarak görülebilen bir devamlılık esasıyla kurulmuştur. Bir işletme, sürdürülebilirlik ile ilgili genel bir zorunluluk olmasa bile, teorik olarak kurumsal sürdürülebilirlik tanımında bahsedilen sürdürülebilir (şimdiki ve gelecekteki paydaşların ihtiyaçlarının karşılanması) faaliyetler yönünde hareket edebilir. Eğer işletme ömrünün zaman sınırı gelecek nesillerin ihtiyaçlarını karşılayamayacak şekilde olsaydı, bu durum sorunlara yol açabilirdi.

- İşletmelerin ekonomik başarılarının altında paydaşların ihtiyaçlarının mümkün olan en iyi şekilde karşılayabilmesi yatar. Faaliyetleri kabul görmeyen bir şirket hayatta kalamaz. Bu kabul görme sadece müşteriler, ortaklar ve çalışanlar gibi aşina olduğumuz paydaşların sağladığı kaynakların dengelenmesiyle ilgili bir konu değildir. Birçok örnek, işletme faaliyetlerinin hükümet dışı çıkar grupları gibi birçok farklı kesim tarafından meşru olarak görülmesinin önemli bir etki yaptığını gösterir.

Kurumsal sürdürülebilirlik, yeni ve gelişen bir kurumsal yönetim paradigması olarak incelenebilir. Geleneksel büyüme ve kar maksimizasyonu modelinin bir alternatifidir. Kurumsal sürdürülebilirliğe ulaşılması için şirketin büyümesi ve kar edebilirliği önemlidir; ancak özellikle ekonomik refah, çevresel bütünlük ve sosyal eşitlik üçlüsünden oluşan sürdürülebilir kalkınmaya ilişkin sosyal amaçlarını da takip etmesi gereklidir (Wilson, 2003: 1).

Kurumsal seviyede sürdürülebilirlik; ekonomik, çevresel ve sosyal faktörlerin kurumsal yönetim ilkeleriyle birlikte işletme faaliyetlerinde ve karar mekanizmalarında uzun vadeli değer yaratmak amacıyla göz önüne alınması ve bu faktörlere ilişkin risklerin etkili yönetilmesiyle kazanılabilir. Bir işletme, kurumsal yönetimin temel ilkeleri olan şeffaflık, eşitlik, hesap verebilirlik ve sorumluluğu benimseyerek, doğayı daha az kirleten teknolojilerle üretim yaparak, çevre koruma bilincini işletmenin bütün kademelerine kazandırarak, tüketicilere sağlıklı ürünler ulaştırarak, çalışanlarına sağlıklı çalışma koşulları sunarak ve haklarını koruyarak, işletme içinde enerji verimliliğini artırarak kurumsal sürdürülebilirliği elde etme adına olumlu adımlar atmış olur. Buradaki örnekler hangi 
sektörde olursa olsun her tür şirketin süreçlerine dahil edilebilecek adımlardır (Borsa İstanbul, 2014: 5).

Sürdürülebilir kalkınmaya yönelik uygulamalara sahip olan işletmeler, ekonomi, çevre ve toplum üzerindeki faaliyetlerinin uzun dönemdeki etkisine bakarak başarılarını ölçerler. İşlerini çevresel ve sosyal sorumluluklarına bağlı kalarak yürütmenin uzun vadede kendi çıkarlarına olacağına inanırlar. Sürdürülebilir kalkınmayı çevresel ve sosyal felaketlerden kaçınmalarına yardım eden önemli bir risk yönetimi olarak görürler. Çevresel sorumluluklar ve koruma programlarının maliyeti, kimyasal sızıntılar, çalışan yaralanmaları, ürünleri geri çağırma, müşteri boykotları ve petrol sızıntılarıyla karşılaştırıldığında çok küçüktür (Clikeman, 2004: 24).

Kurumsal sürdürülebilirlik genel olarak, işletme amaçlarına sosyal ve çevresel sorumluluk bakış açısının kazandırılmasıyla sağlanabilir. Ekonomik, çevresel ve sosyal konular arasındaki amaç çatışmasının uzun dönemde üstesinden gelerek, ekonomik, çevresel ve sosyal başarı amaçları birleştirilebilir. Kurumsal sürdürülebilirliği dikkate alan yeni paradigmaya göre bir işletmenin genel performansı sadece finansal sonuçlara bakılarak tespit edilmez, sosyal ve çevresel performans da genel performansı etkiler. Bu yaklaşım işletme faaliyetlerinden etkilenen ve faaliyetlerini etkileyen bütün taraflara finansal bilgilerin yanında ekonomik, çevresel ve sosyal bilgilerin de raporlanmasını gerektirmektedir.

\section{KURUMSAL SÜRDÜRÜLEBILIRLIK RAPORLAMASI}

Kökeni 19. yüzyıla dayanan finansal raporlama yalnızca parasal ilkelere odaklanarak hazırlanmaktadır. İlk defa 1970'li yıllardan itibaren kapsamını sosyal yönlere doğru genişletmiştir. Finansal raporlamanın kapsamının artmasının temel nedeni şirketin faaliyetleri, ürünleri, hizmetleri ve bunlarla ilişkili pozitif ve negatif sosyal etkiler hakkında iç ve dış paydaşlara bilgi sunma amacıdır. Finansal veriler dışındaki bilgileri sunmayı amaç edinen bu ilk raporlama girişiminin odak noktası, sosyal yönler veya sosyal etki ve kısmen sosyal verimliliktir. Yaklaşık 10 yıl sonra çevresel raporlama ortaya çıkmıştır ve ilk sosyal raporlama faaliyetlerinin kapsamını büyük ölçüde genişletmiştir. Çevresel raporlamanın temel odak noktası, işletme faaliyetlerinin ekonomik, çevresel ve sosyal kaynaklara olan etkisi ya da başka bir ifade ile, atık miktarı, hava ve su emisyonları gibi çevresel etkinin mutlak seviyesidir. Ilerleyen yıllarda raporlama, faaliyetler arasında tek boyutlu bakış açısının yerine, ekonomik ve çevresel boyutlar arasında (ekonomik verimlilik) veya sosyal ve ekonomik boyutlar arasında (sosyal etkinlik) iki boyutlu bağlantı kurmaya başlamıştır (Herzig ve Schalttegger, 2006: 304-305). 2000'li yıllarda kurumsal sosyal sorumluk raporlaması adıyla ortaya çıkarak günümüze kadar gelişerek varlığını sürdüren sürdürülebilirlik raporlaması ise, işletmelerin ekonomik, çevresel ve sosyal faaliyetleri ve bunların arasındaki iki boyutlu bağlantıları hakkında rapor kullanıcılarına bilgi sunma amacını taşır.

Sürdürülebilirlik kavramı ekonomiden çevreye, oradan sosyal konulara kadar birçok boyuta sahiptir.

Sürdürülebilirlik, kurumsal sosyal sorumluluk, kurumsal sorumluluk ve üçlü sorumluluk gibi ekonomik, çevresel ve sosyal çevreye yapılan etkinin anlaşılması gerektiğini dolayısıyla bu boyutların raporlanması gerektiğini ifade eden birçok terim mevcuttur. Benzer anlamlara 
sahip olan bu terimlerin hiçbiri var olan sürdürülebilirlik raporlaması kavramını ifade edememiştir. Kurumlara rehberlik yaparak ve destek olarak sürdürülebilirlik raporlamasını bütün dünyada standart bir uygulama haline getirmek amacıyla hareket eden, bağımsız ve kar amacı gütmeyen bir küresel inisiyatif olan GRI (Global Reporting Initiative), sürdürülebilirlik raporlamasını 'ekonomik, çevresel, sosyal ve yönetişim performans bilgilerinin açıklandığı bir rapor' olarak tanımlamıştır (www.globalreporting.org). Sürdürülebilirlik raporlaması rehberleri bütün dünyada yaygın olarak kullanılan Küresel Raporlama Girişimi'nin sürdürülebilirlik raporlaması tanımını kabul etmektedir. Bu tanım ekonomik, çevresel ve sosyal performans alanlarının yanında bunlara ilişkin yönetişimi de kapsar (English ve Schooley, 2014: 26-27).

Sürdürülebilirlik raporlamasına duyulan ihtiyaç, genel olarak, küresel çapta bir kavram olan sürdürülebilir kalkınmanın işletme ölçeğine yansıması olan kurumsal sürdürülebilirlik kavramının ortaya çıkardığı ekonomik, çevresel ve sosyal sorumlulukların işletme tarafından ne kadar benimsediği ile ilgili bilginin paydaşlar hatta işletmenin kendisi tarafından talep edilmesi ile ortaya çıkmıştır. Günümüzde Asya, Avrupa ve Amerika'da yüzlerce işletme kendi sürdürülebilir kalkınma faaliyetlerini açıklayan periyodik raporlar yayınlamaktadırlar. Finansal raporlamanın doğal bir uzantısı olan sürdürülebilirlik raporları, işletmenin ekonomik, çevresel ve sosyal performansını açıklayarak işletme raporlamasının kapsamını genişletmiştir (Clikeman, 2004: 24).

Sürdürülebilirlik raporlaması da tıpkı finansal raporlama gibi öncelikle paydaşların bilgi ihtiyacı düşünülerek ortaya çıkmıştır. Ancak sürdürülebilirlik raporları sadece bir iletişim aracı değildir. Bu raporların temel özelliklerinden biri de işletmelerin finansal ve finansal olmayan performansları arasındaki bağlantıyı vurgulamalarıdır. Raporlama sürecinde işletmeler, sürdürülebilirlik vizyonları ölçüsünde stratejilerini, politikalarını ve iş planlarını oluşturabilmektedirler. Böylece işletme yönetimi işletmenin artı ve eksi yönlerini tespit edip, geliştirmeleri gereken alanlara odaklanabilecektir (Borsa İstanbul, 2014: 33).

Sürdürülebilirlik raporlaması için yatırımcı birliklerinden çok sayıda talep gelmektedir. Bazı yatırımcılar -korunmuş sosyal yatırım fonları gibi- belirli sosyal ve çevresel kriterlere sahip olan faaliyetleri yürüten işletmelere yatırım yapmaktadırlar. Sosyal sorumluluğu önemseyen yatırımcılar, işletmelerin faaliyet prosedürlerini değerlendirmek için sürdürülebilirlik raporlamasından faydalanırlar. Bazı yatırımcılar ise, kurumsal sürdürülebilirliğin işletmenin uzun dönemli finansal performansını olumlu etkileyeceğine inanırlar (Clikeman, 2004: 24). Bu iki sebepten hareketle birçok borsada işletmelerin sürdürülebilirlik faaliyetlerini ölçen endeksler oluşturulmuştur.

İşletmelerin sürdürülebilirlik raporları hazırlamasının arka planında paydaşlar ve işletmenin kendisi için faydalar sağlaması ve belirlenen birtakım hedeflere ulaşımasını kolaylaştıracağı düşüncesi yatar. Bazı önemli hedefler ve faydalar şöyle sıralanabilir (Herzig ve Schalttegger, 2006: 302):

- Çevresel ve sosyal etkileri yaratan ürünler, hizmetler ve kurumsal faaliyetlerin tanımlanması.

- Kurumsal itibar ve marka değerinin artırılması

- Rekabetçi avantaj sağlanması

- Genel performans göstergeleri olarak sürdürülebilirlik raporlaması ile rekabet üstünlüklerinin belirlenmesi 
- Rakiplere karşı benchmarking ve karşılaştırma

- Işletmede şeffaflığın ve hesap verilebilirliğin artırılması

- İşletme içi bilgi sağlamak, kontrol süreçlerini kurmak ve çalışan motivasyonunu desteklemek

Sürdürülebilirlik raporlaması genellikle finansal raporlamaya ek olarak bağımsız sürdürülebilirlik raporlarının basılı olarak veya internette elektronik versiyonlarının yayınlanması ile rapor kullanıcılarının bilgilendirilmesi şeklinde yürütülür. Bunun dışında bazı işletmeler, faaliyet raporlarının içerisinde, sürdürülebilirlik ile ilgili faaliyetleri hakkında paydaşlarını bilgilendirirler. Bazı işletmeler ise faaliyetleri sonucunda ortaya çıkan ekonomik, çevresel ve sosyal etkileri internet sayfalarındaki bilgilendirmeler, basılı broşürler veya farklı iletişim araçlarını kullanarak kamuoyu ile paylaşırlar. Hangi alternatif tercih edilirse edilsin, sürdürülebilirlik raporlaması süreci, yönetim ve çalışanlar için işletmenin sürdürülebilirlik ile ilgili amaçlarının belirlenmesi, ilgili verinin toplanması ve sürdürülebilirlik bilgisinin yaratılması aşamalarından oluşur. Bu nedenle, sürdürülebilirlik raporları hazırlanırken raporlama süreci ve işletme içi iletişim arasındaki etkileşim göz önüne alınmalıdır (Schaltegger, Bennett, Burritt, 2006: 4).

Kurumsal sürdürülebilirlik raporları belli raporlama çerçeveleri esasında hazırlanmaktadır. Dünya çapında öne çıkan raporlama çerçeveleri, Küresel Raporlama Girişimi (Global Reporting Initiative - GRI) başta olmak üzere aşağıda Tablo 1'de sunulmuştur.

\section{Tablo 1: Sürdürülebilirlik ile İlgili Raporlama Çerçeveleri}

\begin{tabular}{|c|c|c|}
\hline Yוl & Raporlama Adı & Açıklama \\
\hline 1997 & $\begin{array}{l}\text { Küresel Raporlama Girişimi } \\
\text { (Global Reporting Initiative - } \\
\text { GRI) }\end{array}$ & $\begin{array}{l}\text { Bütünleşik sorumluluk raporlaması konusunda dünya çapında en } \\
\text { yaygın olarak kabul görmüş olan inisiyatiftir. Ekonomik, çevresel ve } \\
\text { sosyal performansa ilişkin ilke ve göstergeler belirler. Ekonomik, } \\
\text { çevresel ve sosyal boyutlardan oluşan üçlü sorumluluğu bütünleşik } \\
\text { olarak ele almış, kapsamlı bir çerçeve oluşturmuş ve yayınlamıştır. } \\
\text { İşletmelerin kendi faaliyetlerine ve ürün-hizmetlerine ilişkin } \\
\text { ekonomik, çevresel ve sosyal sonuçlarını raporlayabilmeleri için } \\
\text { sürdürülebilirlik raporlama rehberini oluşturmuştur. }\end{array}$ \\
\hline 1999 & AA1000 (AccountAbility 1000) & $\begin{array}{l}\text { Londra. Bu standart, işletmelerin sosyal ve ahlaki açıdan hesap } \\
\text { verebilirlikleri konusunda genel ilkeler sağlar. Planlama, uygulama, } \\
\text { raporlama ve denetim gibi tüm süreçlerde paydaşlar ile diyalogun } \\
\text { sağlanması gerektiğini açıkça vurgulayan az sayıdaki standarttan } \\
\text { birisidir. İşletmenin günlük faaliyetlerine tüm paydaşlarının dahil } \\
\text { edilmesinin gerekliliğine vurgu yapmak için geliştirilmiştir. }\end{array}$ \\
\hline 2000 & $\begin{array}{l}\text { Birleşmiş Milletler Küresel } \\
\text { Illkeler Sözleşmesi (UN Global } \\
\text { Compact - UNGC) }\end{array}$ & $\begin{array}{l}\text { New York. Bu sözleşme, şirketlerden etki alanları kapsamında insan } \\
\text { hakları, çalışma standartları, çevre ve yolsuzlukla mücadele } \\
\text { alanlarında bir dizi esas değeri kabul etmeleri, desteklemeleri ve } \\
\text { uygulamaya koymalarına ilişkin ilkeler içermektedir. }\end{array}$ \\
\hline 2000 & $\begin{array}{l}\text { İlerleme Bildirimi Raporlaması } \\
\text { (Communication on Progress - } \\
\text { COP) }\end{array}$ & $\begin{array}{l}\text { UNGC'nin insan hakları, çalışma standartları, çevre ve yolsuzluğa } \\
\text { ilişkin } 10 \text { prensibini referans alır. }\end{array}$ \\
\hline 2000 & OECD Çok Uluslu Şirketler & Devletler tarafından çokuluslu işletmelere yapılan tavsiyelerdir. \\
\hline
\end{tabular}




\begin{tabular}{|c|c|c|}
\hline & $\begin{array}{l}\text { Genel ilkeleri (The OECD } \\
\text { Guidelines for Multinational } \\
\text { Enterprises) }\end{array}$ & $\begin{array}{l}\text { Aralarında Türkiye'nin de bulunduğu } 46 \text { ülke tarafından kabul } \\
\text { edildiği ve bu ülkelerde faaliyet gösteren veya bu ülkeler menşeli } \\
\text { çok uluslu şirketlerin faaliyetlerinin hükümet politikalarıyla } \\
\text { uyumunun sağlanması, faaliyette bulundukları toplum ile kuruluşlar } \\
\text { arasındaki karşılıklı anlayış ve güvenin sağlamlaştıııması ve yabancı } \\
\text { yatırımlar için uygun bir iş ortamı sağlayarak çok uluslu kuruluşların } \\
\text { sürdürülebilir kalkınmaya katkısının artırılması amaçlarını } \\
\text { taşımaktadır. }\end{array}$ \\
\hline 2006 & $\begin{array}{l}\text { IFC Performans Standartları } \\
\text { (IFC Performance Standards) }\end{array}$ & $\begin{array}{l}\text { Sosyal ve çevresel değerlendirmede risklerin yönetilmesine dair } \\
\text { standartlardır. }\end{array}$ \\
\hline 2008 & $\begin{array}{l}\text { Karbon Saydamlık Projesi } \\
\text { (Carbon Disclosure Project - } \\
\text { CDP) }\end{array}$ & $\begin{array}{l}\text { Raporlamanın ana başlıkları iklim değişikliği, su kullanımı, ormanlara } \\
\text { verilen zarar, tedarik zincirlerinin çevresel riskleridir. }\end{array}$ \\
\hline 2010 & $\begin{array}{l}\text { Entegre Raporlama (Integrated } \\
\text { Reporting - IR) }\end{array}$ & $\begin{array}{l}\text { Entegre raporlama, kurumun stratejisi, yönetim ve finansal } \\
\text { performansı ile faaliyet gösterdiği alandaki ekonomik, çevresel ve } \\
\text { sosyal faktörler arasındaki bağlantıyı tanımlar. }\end{array}$ \\
\hline 2010 & ISO 26000 & $\begin{array}{l}\text { 1998'de yayınlanan SA } 8000 \text { Standardı olarak bilinmektedir. Kamu } \\
\text { kurumlarından sivil toplum kuruluşlarına, gelişmiş ülkelerden } \\
\text { gelişmekte olan ülkelere tüm kurumların yararlanabileceği bir } \\
\text { kılavuzdur. Işletmelerin, kamu kurumlarının, sivil toplum } \\
\text { örgütlerinin yararlanabileceği kılavuz niteliğindeki bu standart, } \\
\text { sürdürülebilir kalkınmayı destekleyen sosyal sorumluluk } \\
\text { kavramlarının tamamlayıcısı olmuştur. }\end{array}$ \\
\hline
\end{tabular}

GRI, dünyada yaygın bir şekilde kullanılan kapsamlı bir sürdürülebilirlik raporlaması çerçevesidir. GRI, sürdürülebilirlik raporlaması çerçevesi kapsamında, raporlama ilkeleri ile kuruluşların ekonomik, çevresel ve sosyal performanslarını ölçmeleri ve raporlamaları için gereken ilke ve göstergeleri belirlemektedir. GRI yıllar içinde güncellenerek yeni versiyonları ortaya çıkmıştır. İlk GRI rehberi 2000 yılında yayınlandıktan sonra, 2002, 2006 ve 2011 yılında güncellenmiş ve 2013 yılında ise son haliyle yayınlanmıştır. Bu süreç ise aşağıda Şekil 1'de gösterilmiştir.

\section{Şekil 1: GRI'nın Gelişim Süreci}

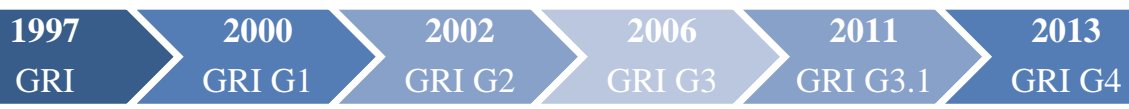

Ülkemizde ve dünyada sürdürülebilirlik çalışmaları amacıyla kurulan çeşitli kuruluşlar vardır. Bu kuruluşlar Tablo 2'de gösterilmiştir.

Tablo 2: Sürdürülebilirlik ve Sürdürülebilirlik Raporlaması ile İlgili Kuruluşlar

\begin{tabular}{|l|l|l|}
\hline Yıl & Kuruluşlar & Açıklama \\
\hline 1992 & $\begin{array}{l}\text { Dünya Sürdürülebilir Kalkınma } \\
\begin{array}{l}\text { I̧ Konseyi (World Business } \\
\text { Council for Sustainable } \\
\text { Development - WBCSD) }\end{array}\end{array}$ & $\begin{array}{l}\text { Ekonomik büyüme, ekolojik denge ve sosyal gelişim konularından } \\
\text { yola çıkarak 3 ana faktör yoluyla sürdürülebilir kalkınma üzerine } \\
\text { ortak taahhütlerini ortaya koyan uluslararası 209 şirketin } \\
\text { koalisyonundan oluşmaktadır. }\end{array}$ \\
\hline
\end{tabular}




\begin{tabular}{|c|c|c|}
\hline & & $\begin{array}{l}2004 \text { yılında Iş Dünyası ve Sürdürülebilir Kalkınma Derneği (SKD } \\
\text { Türkiye) kurulmuştur. Dünya Sürdürülebilir Kalkınma İş Konseyi } \\
\text { (WBCSD)'nin Türkiye'deki tek iş ortağı ve temsilcisidir. }\end{array}$ \\
\hline 1995 & $\begin{array}{l}\text { Avrupa Kurumsal Sosyal } \\
\text { Sorumluluk Birliği (CSR } \\
\text { Europe) }\end{array}$ & $\begin{array}{l}\text { Kurumsal sosyal sorumluluk kavramının uluslararası standartlarda } \\
\text { yaygınlaşmasını ve sosyal sorumluluk bilincini uluslararası alanda } \\
\text { tanıtmayı amaçlayan dernek, bu kapsamda sürdürülebilir kalkınma, } \\
\text { kurumsal yönetişim ve kamu-özel sektör-sivil toplum ortaklıklarını } \\
\text { temel alan bir yaklaşım ile gönüllülük esası ile faaliyetlerini } \\
\text { sürdürmektedir. } \\
2005 \text { yılında Türkiye Kurumsal Sosyal Sorumluluk Derneği } \\
\text { kurulmuştur. } 2008 \text { yılından beri de CSR Europe'nin üyesidir. }\end{array}$ \\
\hline 2000 & $\begin{array}{l}\text { Birleşmiş Milletler Küresel } \\
\text { Illkeler Sözleşmesi (UN Global } \\
\text { Compact - UNGC) }\end{array}$ & $\begin{array}{l}\text { Sürekli rekabet içindeki iş dünyasına ortak bir kalkınma kültürü } \\
\text { oluşturmak üzere evrensel ilkeler öneren yenilikçi bir kurumsal } \\
\text { sorumluluk yaklaşımıdır. Vizyonu, "Sürdürülebilir ve kapsamlı } \\
\text { küresel ekonomi" olan Global Compact'e taraf olmak tamamen } \\
\text { gönüllülük esasına dayanmaktadır. Farklı millet, dil, kültür } \\
\text { bağlamlarında benimsenmesi amacına hizmet eden ulusal ağlar, } \\
\text { aynı zamanda şirketlerin bir araya gelerek sürdürülebilirlik } \\
\text { konularında harekete geçmeleri için önemli bir platform } \\
\text { oluşturmaktadır. } \\
2002 \text { yılında Global Compact Türkiye kurulmuştur. }\end{array}$ \\
\hline 2008 & $\begin{array}{l}\text { Karbon Saydamlık Projesi } \\
\text { (Carbon Disclosure Project - } \\
\text { CDP) }\end{array}$ & $\begin{array}{l}\text { İklim değişikliğinin etkilerini azaltmak ve doğal kaynakları korumak } \\
\text { amacıyla iş dünyasının işleyiş şeklini değiştirmek üzere çalışır. } \\
2010 \text { yılında Carbon Disclosure Project (CDP) Türkiye kurulmuştur. }\end{array}$ \\
\hline 2010 & $\begin{array}{l}\text { Uluslararası Entegre } \\
\text { Raporlama Konseyi } \\
\text { (International Integrated } \\
\text { Reporting Council - IIRC) }\end{array}$ & $\begin{array}{l}\text { Düzenleyici kurumlar, yatırımcılar, şirketler, standart belirleme } \\
\text { otoriteleri, muhasebe uzmanları ve STK'lar tarafından kurulmuş } \\
\text { küresel bir koalisyondur. Bu koalisyon, kurumsal raporlama } \\
\text { sürecinin gelişiminde bir sonraki adımın değer yaratma hakkında } \\
\text { iletişim kurmak olduğu görüşüne sahiptir. }\end{array}$ \\
\hline 2011 & $\begin{array}{l}\text { Sürdürülebilirlik Muhasebesi } \\
\text { Standartları Kurulu }\end{array}$ & $\begin{array}{l}\text { Borsaya kayıtlı Amerikan şirketleri tarafından önemli } \\
\text { sürdürülebilirlik hususlarının yatırımcılar ve kamu yararına } \\
\text { açıklanmasında kullanılmak üzere sürdürülebilirlik muhasebesi } \\
\text { standartları oluşturan ve kar amacı gütmeyen bağımsız bir } \\
\text { kuruluştur. }\end{array}$ \\
\hline
\end{tabular}

Dünyada sürdürülebilirliğin ölçülmesi için, çeşitli sürdürülebilirlik endeksleri hesaplanmaktadır. Tablo 3 'te sürdürülebilirlik endekslerinden önemli olanlarından bazılarına yer verilmiştir.

Tablo 3: Sürdürülebilirlik ile Iilgili Endeksler

\begin{tabular}{|l|l|l|}
\hline Yıl & Endeksler & Açıklama \\
\hline 1990 & $\begin{array}{l}\text { Domini 400 Sosyal Endeksi } \\
\text { (Domini 400 Social Index) }\end{array}$ & $\begin{array}{l}\text { Kurumsal yatırımcılara yönelik araştırmalar yapan ve endeksler } \\
\text { üren bir şirket olan "KLD Research \& Analytics" tarafından } \\
\text { hesaplanmaya başlanmıştır. Dünyadaki ilk sürdürülebilirlik } \\
\text { endeksidir. }\end{array}$ \\
\hline
\end{tabular}




\begin{tabular}{|c|c|c|}
\hline 1999 & $\begin{array}{l}\text { Dow Jones Sürdürülebilirlik } \\
\text { Endeksi (Dow Jones } \\
\text { Sustainability World Index - } \\
\text { DJSI) }\end{array}$ & $\begin{array}{l}\text { Dow Jones Sürdürülebilirlik Grubu tarafından geliştirilmiştir. Bu } \\
\text { endeks yatıımcılara ve finansal analistlere şirketleri sürdürülebilirlik } \\
\text { performanslarına göre değerleyebilecekleri bir araç sunmaktadır. }\end{array}$ \\
\hline 2001 & $\begin{array}{l}\text { FTSE4Good Endeksi } \\
\text { (FTSE4Good Index) }\end{array}$ & $\begin{array}{l}\text { Londra. İşletmelerde sürdürülebilir çevresel konularda çalışmalar } \\
\text { gerçekleştirmek, paydaşlar ile olumlu ilişkiler geliştirmek, evrensel } \\
\text { insan haklarını desteklemek vb. konuları içeren bir sosyal } \\
\text { sorumluluk yatırım endeksidir. }\end{array}$ \\
\hline 2004 & $\begin{array}{l}\text { JSE Sorumlu Yatırım Endeksi } \\
\text { Endeksi (JSE Socially } \\
\text { Responsible Investment (SRI) } \\
\text { Index) }\end{array}$ & $\begin{array}{l}\text { Güney Afrika, Johanesburg borsası. Gelişmekte olan ülkelerin } \\
\text { borsaları içinde ilk sürdürülebilirlik endeksidir. }\end{array}$ \\
\hline 2005 & $\begin{array}{l}\text { Çevresel Sürdürülebilirlik } \\
\text { Endeksi (Environmental } \\
\text { Sustainability Index - ESI) }\end{array}$ & $\begin{array}{l}\text { Endeks, Dünya Ekonomik Forumu Geleceğin Küresel Liderleri } \\
\text { Çalışma Grubu, Colombia Üniversitesi Yerbilimi Bilgi Merkezi ve Yale } \\
\text { Üniversitesi Çevre Hukuku ve Politikası Merkezinin ortak } \\
\text { çalışmalarıyla hazırlanmıştır. Bu endeks dünya ülkeleri için } \\
\text { geliştirilen ve ülkelerin çevresel sürdürülebilirlik alanındaki } \\
\text { ilerlemelerini izlemeyi hedefleyen bir araçtır. Çevre sistemleri, çevre } \\
\text { sorunları, insanların risklerden korunması, çevresel risklere karşı } \\
\text { toplumsal ve kurumsal mücadele kapasitesi, küresel ortak } \\
\text { problemlerde diğer ülkelerle işbirliği bu endeksin temel unsurlarıdır. }\end{array}$ \\
\hline 2014 & BIST Sürdürülebilirlik Endeksi & $\begin{array}{l}\text { Türkiye, Borsa İstanbul. Endeksin amacı, Borsa İstanbul'da işlem } \\
\text { gören ve kurumsal sürdürülebilirlik performansları üst seviyede olan } \\
\text { şirketlerin yer alacağı bir endeks oluşturulması, Türkiye'de ve } \\
\text { özellikle Borsa İstanbul şirketleri arasında sürdürülebilirlik } \\
\text { konusundaki anlayış, bilgi ve uygulamaların artmasıdır. }\end{array}$ \\
\hline
\end{tabular}

Türkiye'de 4 Kasım 2014 tarihi itibarıyla BIST Sürdürülebilirlik Endeksi hesaplanmaya başlanmıştır. BIST Sürdürülebilirlik Endeksi'nde yer alan şirketler; Akbank, Arçelik, Aselsan, Garanti Bankası, Koç Holding, Migros, Petkim, Sabancı Holding, TAV Havalimanları, Tofaş, Turkcell, Tüpraş, Türk Telekom, Vakıfbank ve Yapı Kredi Bankası'dır. Toplam 15 şirket, BIST Sürdürülebilirlik Endeksi'nde yer almaktadır.

1 Günümüzde, gelişmekte olan ülkelerin sürdürülebilirlik endeksleri genellikle ülke borsaları tarafından oluşturulmaktadır. Bu duruma örnek olarak gelişmekte olan ülkelerin borsalarına ait hesaplanan sürdürülebilirlik endeksleri yıl-endeks adı ve ait olduğu borsa sırasıyla aşağıda verilmiştir.

2005 - Kurumsal Sürdürülebilirlik Endeksi (Corporate Sustainability Index) - Brezilya, BM\&FBOVESPA borsası.

2009 - SSE SRI Endeksi (SSE SRI Index) - Çin, Şangay borsası.

2009 - SRI KEHATI Endeksi (SRI KEHATI Index) - Endonezya, Endonezya borsasI.

2009 - Kore SRI Endeksi (Korean SRI Index) - Kore, Kore borsasI.

2010 - S\&P EGX ESG Endeksi (S\&P EGX ESG Index) - Mısır, Mısır borsası. 


\section{ARAŞTIRMA}

Bu çalışmada Türkiye'deki kurumsal sürdürülebilirliğin durumunun incelenmesi amaçlanmaktadır. Bu amaçla 2015 Mayıs ayı itibariyle kurumsal sürdürülebilirlik portalında (www.kurumsalsurdurulebilirlik.com) yer alan veriler doğrultusunda Türkiye'deki kurumsal sürdürülebilirlik raporları incelenmiştir. Bu portaldan elde edilen verilere göre Türkiye'de kurumsal sürdürülebilirlik raporu yayınlayan 72 kuruluş ${ }^{2}$ bulunmakta ve bu kuruluşlar toplamda 181 kurumsal sürdürülebilirlik raporu yayınlamışlardır. Çalışmada kurumsal sürdürülebilirlik raporu yayınlayan kuruluşların sektör dağılımı, büyüklükleri, halka açıklık, borsada işlem görme, çalışan sayısı, ciro, GRI OS (Global Reporting Initiative Organizational Stakeholders) üyeliği, UNGC (United Nations Global Compact) üyeliği ve yayınlanan kurumsal sürdürülebilirlik raporlarının türü, yayınlanma yılları, raporlama dönemi, rapor dili, GRI uygulama düzeyi, GRI uygulama beyanı, referans, bağımsız denetimden geçme, denetim sağlayıcısı, sektör eklentisi, paydaş paneli/uzman görüşü ölçüt olarak belirlenmiştir. Çalışma kapsamındaki kuruluşlara ait bilgiler (büyüklük, halka açıklık, borsada işlem görme, çalışan sayısı, ciro vs.) 2014 yılı verilerini içermektedir.

\section{Grafik 1: Kuruluş Sektörleri}

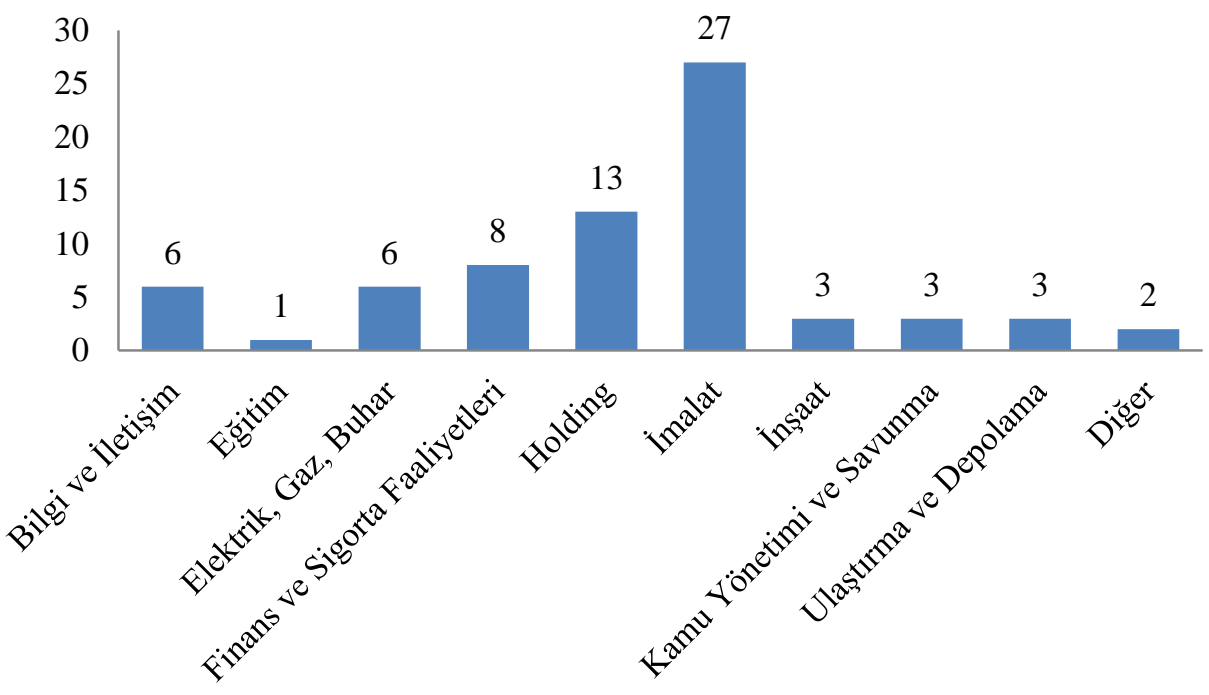

Araştırma kapsamındaki kuruluşların sektör bazında dağılımı Grafik 1'de gösterilmiştir. Araştırma kapsamında incelenen 72 kuruluş, 10 sektör $^{3}$ altında toplanmıştır (Ek 1).

2 BIST Sürdürülebilirlik Endeksi içinde yer alan 15 kuruluştan, www.kurumsalsurdurulebilirlik.com internet adresinde sürdürülebilirlik raporları yer almayan kuruluşlar ise şunlardır: Migros, Petkim, Sabancı Holding, Türk Telekom ve Vakıfbank.

${ }^{3}$ Bilgi ve Illetişim sektörünün alt sektörleri; Telekomünikasyon, Bilgisayar Programlama, Danışmanlık ve illgili Faaliyetler.

Eğitim sektörünün alt sektörleri; Eğitim.

Elektrik, Gaz, Buhar sektörünün alt sektörleri; Elektrik, Gaz, Buhar. 
Kuruluşların sektör sınıflaması NACE kodlarına göre yapılmıştır. Buna göre bilgi ve iletişim sektöründe 6 kuruluş, eğitim sektöründe 1 kuruluş, elektrik, gaz, buhar ve iklimlendirme üretimi ve dağıtımı sektöründe 6 kuruluş, finans ve sigorta faaliyetleri sektöründe 8 kuruluş, imalat sektöründe 27 kuruluş, inşaat sektöründe 3 kuruluş, kamu yönetimi ve savunma sektöründe 3 kuruluş, ulaştırma ve depolama sektöründe 3 kuruluş faaliyet göstermektedir. Ayrıca 13 kuruluş holding ve 2 kuruluş da diğer kategorisinde toplanmıştır.

\section{Grafik 2: İmalat Sektörü Dağılımı}

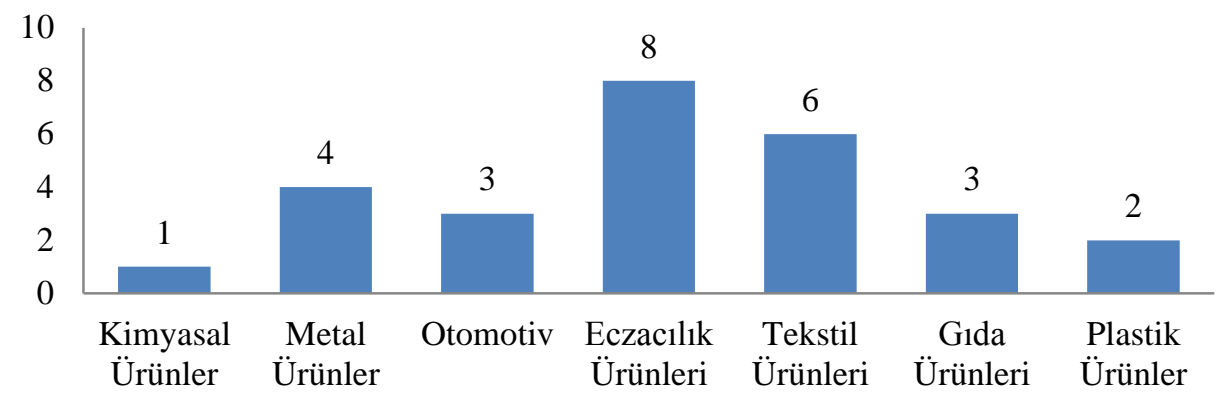

Araştırma kapsamındaki kuruluşların imalat sektörünün alt sektörlerine göre dağılımı Grafik 2'de gösterilmiştir. Buna göre 1 kuruluş kimyasal ürünler, 4 kuruluş metal ürünler, 3 kuruluş otomotiv, 8 kuruluş eczacılık ürünleri, 6 kuruluş tekstil ürünleri, 3 kuruluş gıda ürünleri ve 2 kuruluş da plastik ürünler imalatı alt sektörlerinde faaliyet göstermektedir.

\section{Grafik 3: Kuruluş Büyüklükleri}

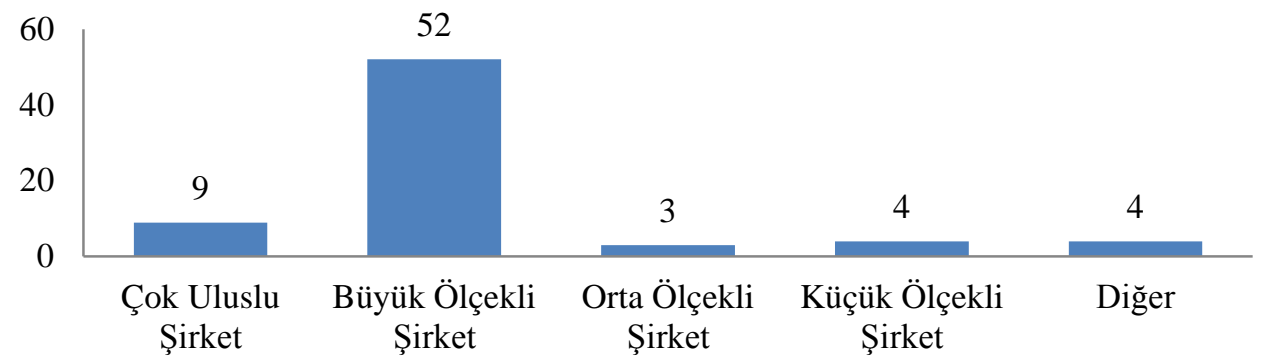

Finans ve Sigorta Faaliyetleri sektörünün alt sektörleri; Finansal Hizmet Faaliyetleri.

Holding sektörünün alt sektörleri; Holding,

Imalat sektörünün alt sektörleri; Tekstil Ürünleri, Gıda Ürünleri, Kimya Ürünleri, Metal Ürünler, Eczacılık Ürünleri, Otomotiv, Plastik Ürünler.

inşaat sektörünün alt sektörleri; İnşaat.

Kamu Yönetimi ve Savunma sektörünün alt sektörleri; Kamu Yönetimi ve Savunma.

Ulaştırma ve Depolama sektörünün alt sektörleri; Ulaştırma ve Depolama.

Diğer sektörünün alt sektörleri; Kar Amacı Gütmeyen Kuruluşlar. 
Araştırma kapsamındaki kuruluşların büyüklüklerine göre dağılımı Grafik 3'te gösterilmiştir. Buna göre, araştırma kapsamındaki 72 kuruluşun 9'u çok uluslu şirket, 52'si büyük ölçekli şirket, 3’ü orta ölçekli şirket, $4^{\prime}$ ü küçük ölçekli şirket ve $4^{\prime}$ ü de diğer ${ }^{4}$ türündedir.

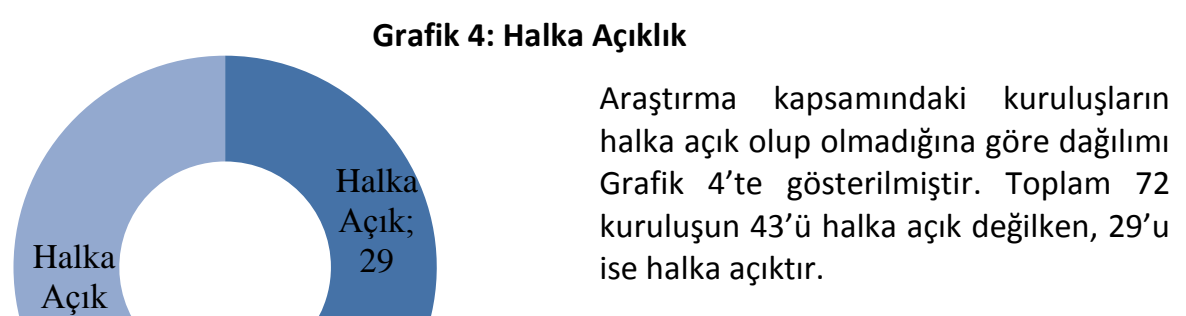

\section{Grafik 5: Borsada İşlem Görme}

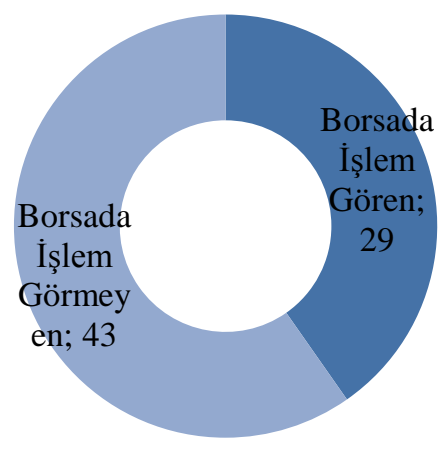

Araştırma kapsamındaki kuruluşların borsada işlem görme durumuna göre dağılımı Grafik 5'te gösterilmiştir. 72 kuruluşun 43'ü borsada işlem görmemekte ve $29^{\prime} u$ ise borsada işlem görmektedir.

\section{Grafik 6: Çalışan Sayısı}

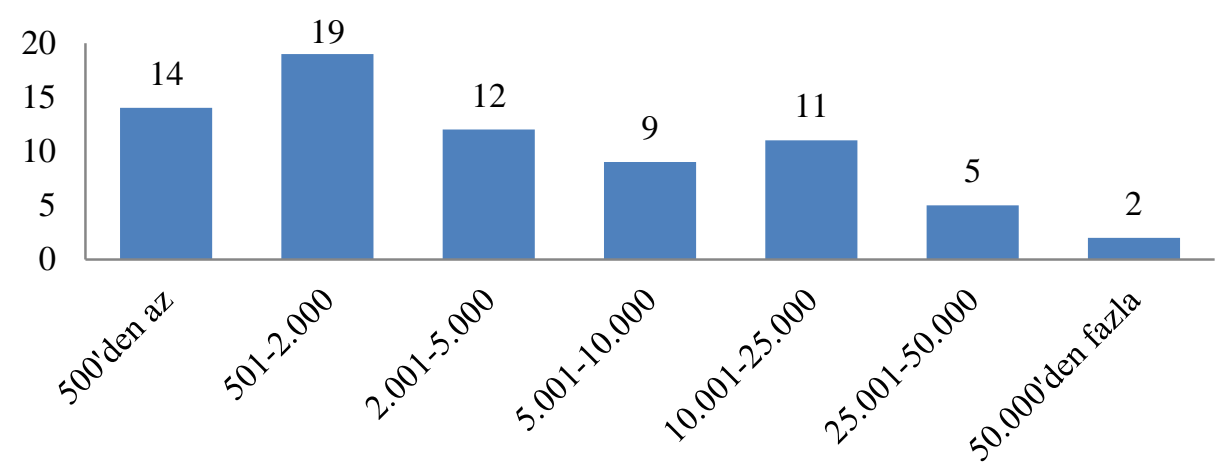

\footnotetext{
${ }^{4}$ Kamu kuruluşları, üniversiteler ve kar amacı gütmeyen kuruluşlar.
} 
Araştırma kapsamındaki kuruluşların çalışan sayısına göre dağılımı Grafik 6'da gösterilmiştir. Buna göre çalışan sayısı 500'den az 14 kuruluş, 501-2.000 arası 19 kuruluş, 2.001-5.000 arası 12 kuruluş, 5.001-10.000 arası 9 kuruluş, 10.001-25.000 arası 11 kuruluş, 25.001-50.000 arası 5 kuruluş ve 50.000'den fazla 2 kuruluş bulunmaktadır.

Grafik 7: Ciro

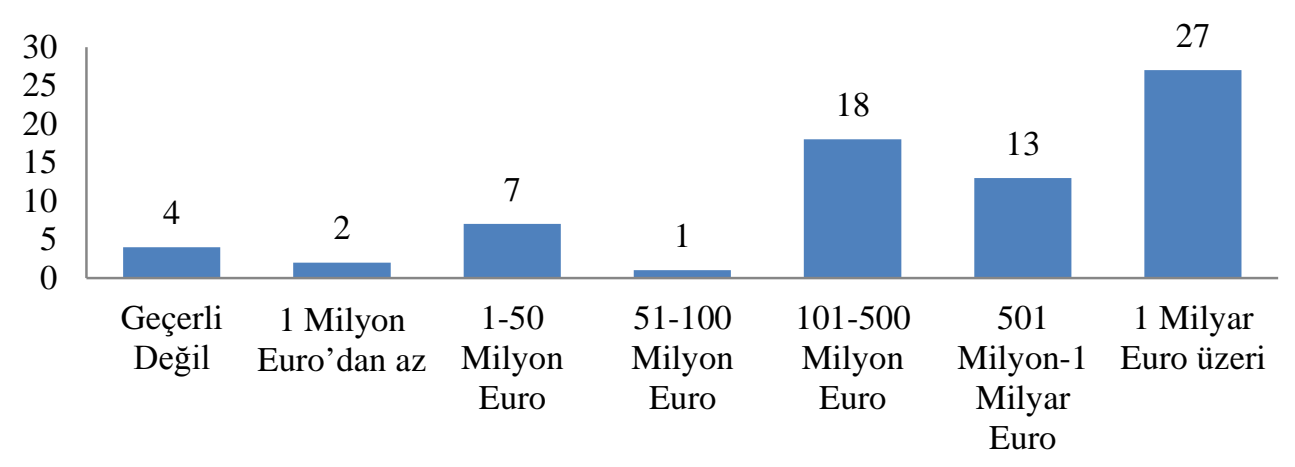

Araştırma kapsamındaki kuruluşların cirosuna göre dağılımı Grafik 7'de gösterilmiştir. Buna göre cirosu 1 milyon Euro'dan az 2 kuruluş, 1-50 milyon Euro arası 7 kuruluş, 51-100 milyon Euro 1 kuruluş, 101-500 milyon Euro 18 kuruluş, 501 milyon-1 milyar Euro arası 13 kuruluş ve 1 milyar Euro üzeri 27 kuruluş bulunmaktadır.

\section{Grafik 8: GRI OS (Global Reporting Initiative - Organizational Stakeholders / Kurumsal Paydaş Programı) Üyeliği}

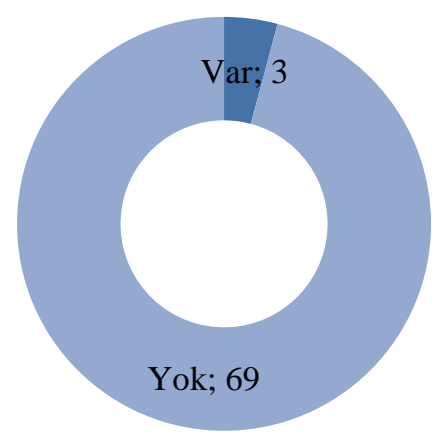

Araştırma kapsamındaki kuruluşların GRI OS üyeliğine göre dağılımı Grafik 8 'de gösterilmiştir. Buna göre 3 kuruluşun GRI OS üyeliği mevcutken; 69 kuruluşun GRI OS üyeliği bulunmamaktadır. 


\section{Grafik 9: UNGC (United Nations Global Compact / Birleşmiş Milletler Küresel illkeler Sözleşmesi) Üyeliği}

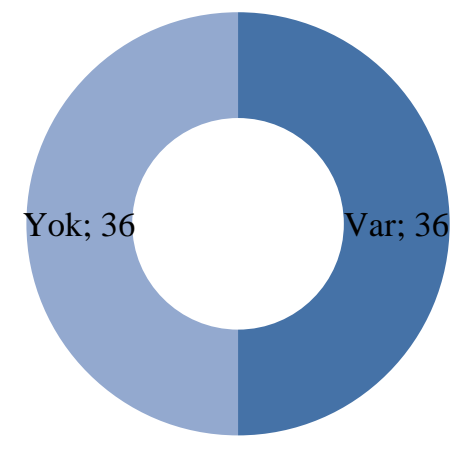

Araştırma kapsamındaki kuruluşların UNGC üyeliğine göre dağılımı Grafik 9'da gösterilmiştir. Buna göre 36 kuruluşun UNGC üyeliği bulunmaktayken; 36 kuruluşun UNGC üyeliği bulunmamaktadır.

\section{Grafik 10: Rapor Türü}

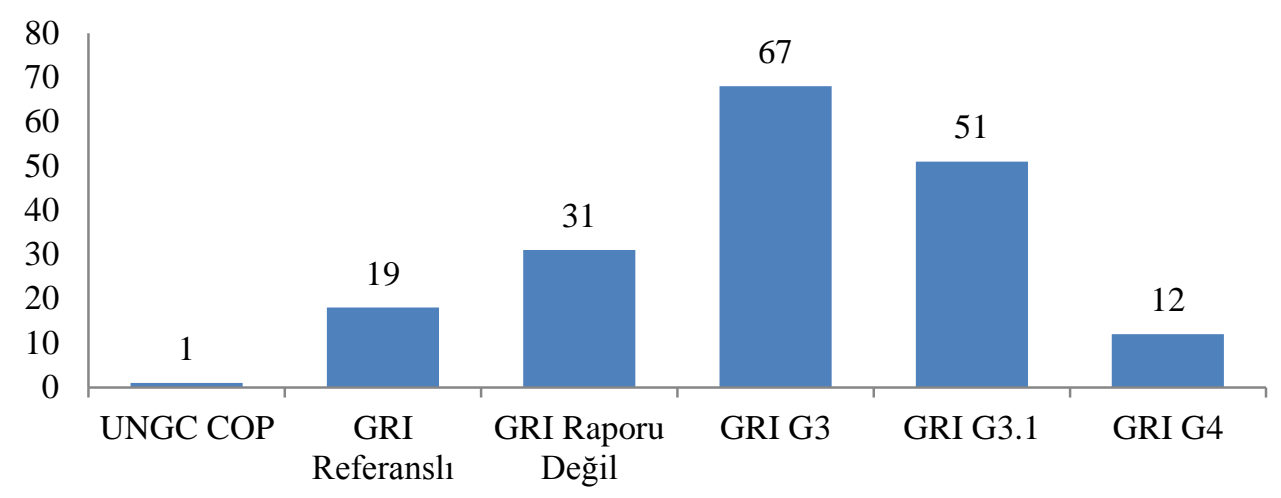

Araştırma kapsamındaki raporların türlerine göre dağılımı Grafik 10'da gösterilmiştir. Grafik 10 incelendiğinde, toplam 181 sürdürülebilirlik raporlarının türlerine göre dağıımı görülmektedir. Raporların 1'i UNGC COP, 19'u GRI referanslı, 31'i GRI raporu değildir. GRI'ya göre yayınlanan raporların ise 67 'si GRI G3, 51'i GRI G3.1 ve 12 'si ise GRI G4 türündedir. Bu verilere göre toplam 130 rapor GRI türünde yayınlanmıştır. 


\section{Grafik 11: Rapor Yayınlanma Yılları}

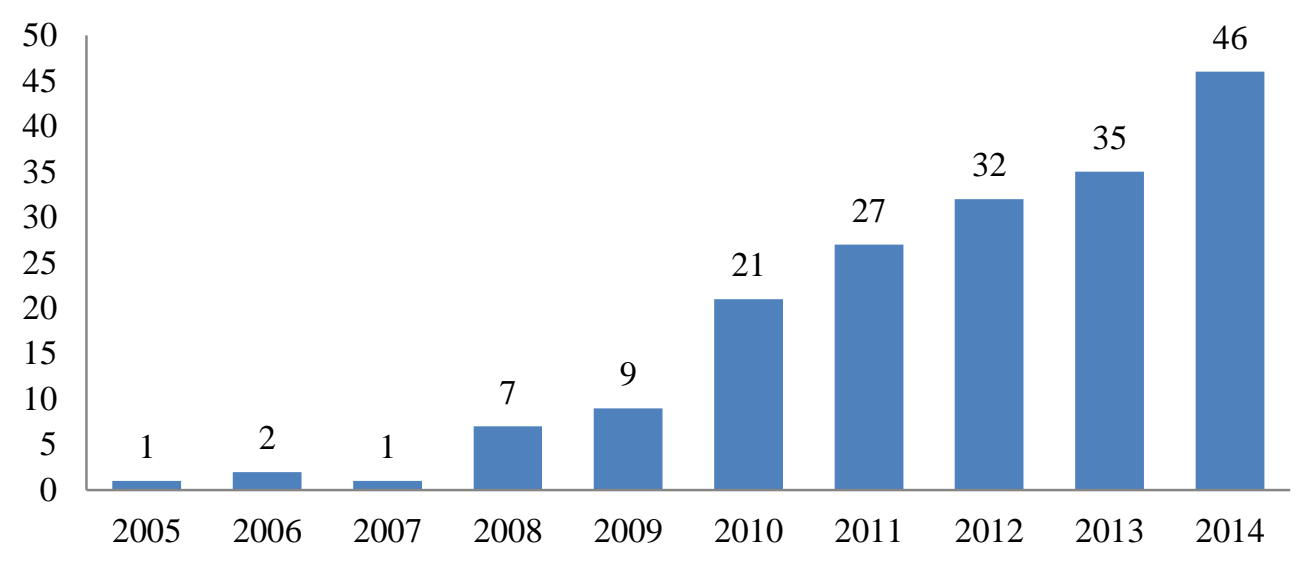

Araştırma kapsamındaki raporların yayınlanma yıllarına göre dağılımı Grafik 11'de gösterilmiştir. Grafik 11'e bakıldığında, Türkiye'de sürdürülebilirlik raporlarının 2005 yılından itibaren yayınlanmaya başladığı görülmektedir. Bu verilere göre 2005 yılında 1, 2006 yılında 2, 2007 yılında 1, 2008 yılında 7, 2009 yılında 9, 2010 yılında 21, 2011 yılında 27, 2012 yılında 32, 2013 yılında 35 ve 2014 yılında ise 46 rapor yayınlanmıştır. Grafikten de görüldüğü gibi sürdürülebilirlik raporları yayınlanması giderek artmaktadır.

\section{Grafik 12: 2014 Yılı Sürdürülebilirlik Raporları}

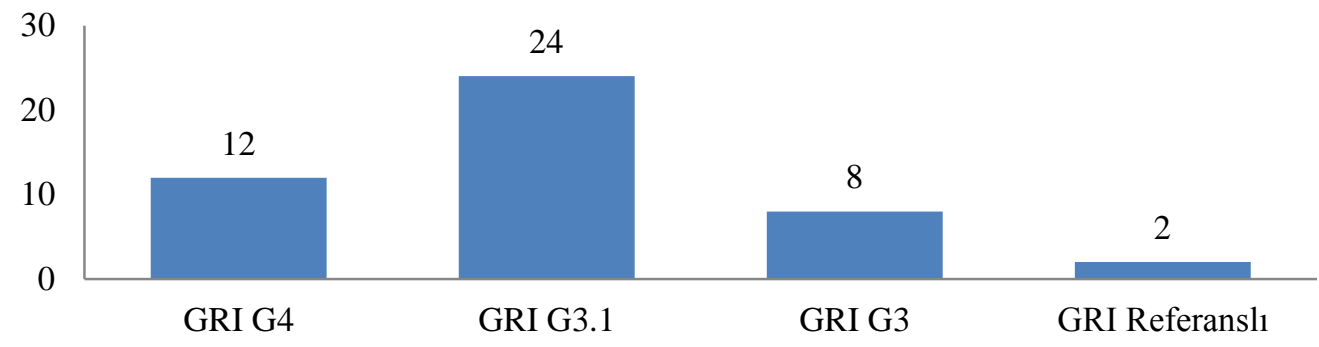

Araştırma kapsamındaki 2014 yılında yayınlanan raporların türlerine göre dağılımı Grafik 12 'de gösterilmiştir. 2014 yılında yayınlanan toplam 46 rapor GRI'yı temel almıştır. GRI G4 rehberinin 31.12.2015 tarihinden sonra uygulanacak olmasından dolayı diğer GRI türlerinde de raporların yayınlandığı görülmektedir. Buna göre, 12 rapor GRI G4 türünde, 24 rapor GRI G3.1 türünde, 8 rapor GRI G3 türünde ve 2 rapor ise GRI referanslı yayınlanmıştır. 


\section{Grafik 13: Raporlama Dönemi}

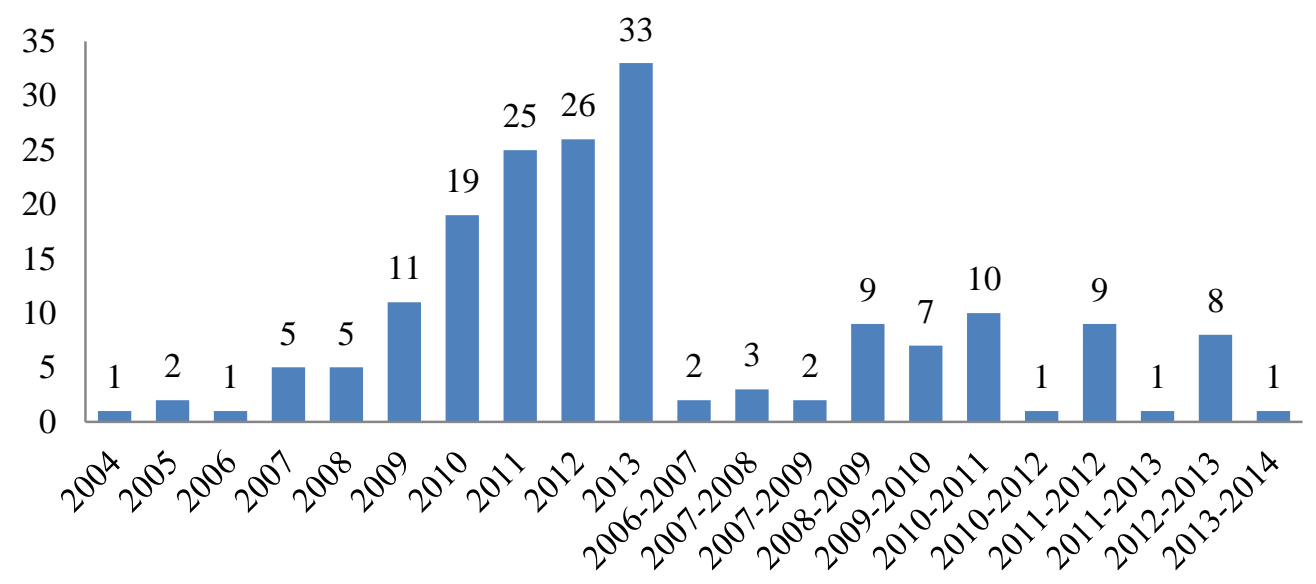

Araştırma kapsamındaki raporların raporlama dönemlerine göre dağılımı Grafik 13'te gösterilmiştir. Buna göre raporlama dönemi başlangıç yılı 2004'tür. Yayınlanan sürdürülebilirlik raporlarının 1 yıllık ve 2 yıllık dönemler bazında hazırlandığı görülmektedir. 1 yıllık dönemi kapsayan raporlar dikkate alındığında toplam 128 rapor olduğu görülmektedir. 2004 dönemini kapsayan 1, 2005 dönemini kapsayan 2, 2006 dönemini kapsayan 1, 2007 dönemini kapsayan 5, 2008 dönemini kapsayan 5, 2009 dönemini kapsayan 11, 2010 dönemini kapsayan 19, 2011 dönemini kapsayan 25, 2012 dönemini kapsayan 26 ve 2013 dönemini kapsayan ise 33 rapor yayınlanmıştır. 2 yıllık dönemi kapsayan raporlar dikkate alındığında toplam 53 rapor olduğu görülmektedir. 2006-2007 dönemlerini kapsayan 2, 2007-2008 dönemlerini kapsayan 3, 2007-2009 dönemlerini kapsayan 2, 2008-2009 dönemlerini kapsayan 9, 2009-2010 dönemlerini kapsayan7, 2010-2011 dönemlerini kapsayan 10, 2010-2012 dönemlerini kapsayan 1, 2011-2012 dönemlerini kapsayan 9, 2011-2013 dönemlerini kapsayan 1, 2012-2013 dönemlerini kapsayan 8 ve 2013-2014 dönemlerini kapsayan 1 rapor yayınlanmıştır.

\section{Grafik 14: Rapor Dili}

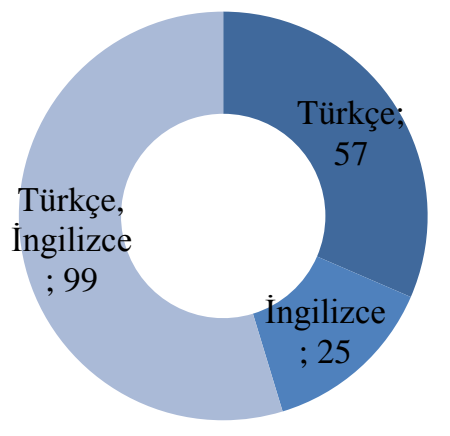

Araştırma kapsamındaki raporların rapor dillerine göre dağılımı Grafik 14 'te gösterilmiştir. Yayınlanan 181 sürdürülebilirlik raporunun 57 'si Türkçe, 25'i Ingilizce ve 99'u ise Türkçe/Ingilizce'dir. 


\section{Grafik 15: GRI Uygulama Düzeyi}

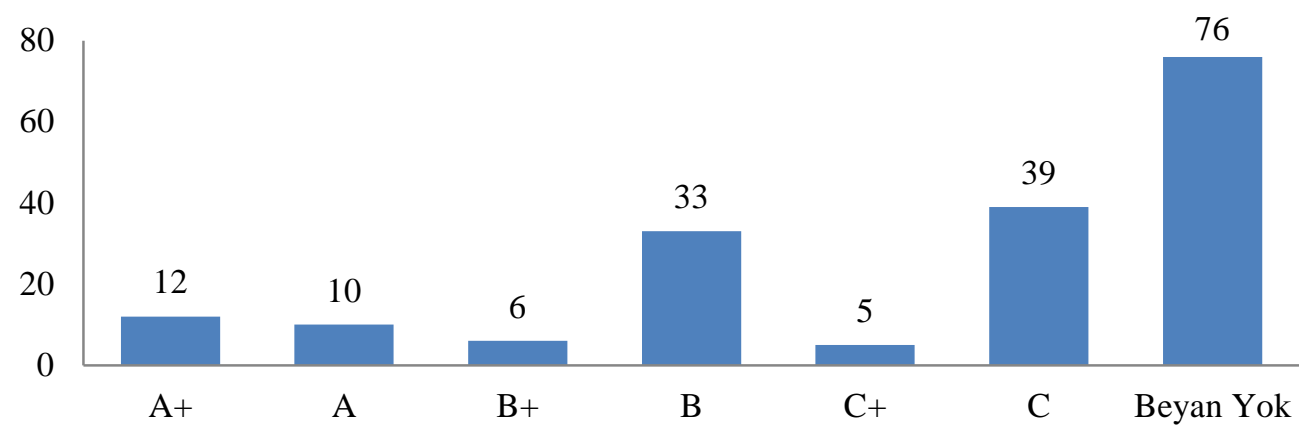

Araştırma kapsamındaki raporların GRI uygulama düzeyine göre dağılımı Grafik 15'te gösterilmiştir. Buna göre, $A+$ düzeyinde 12 , A düzeyinde $10, B+$ düzeyinde 6 , $B$ düzeyinde 33, C+ düzeyinde 5, C düzeyinde 39 rapor yayınlanmıştır. Ayrıca GRI uygulama düzeyi beyan edilmeyen 76 rapor vardır ve bu 76 raporun 12 tanesi GRI G4'e göre hazırlandığından, 51 tanesi de GRI raporu olmadığından uygulama düzeyi yoktur.

\section{Grafik 16: GRI Uygulama Beyanı}

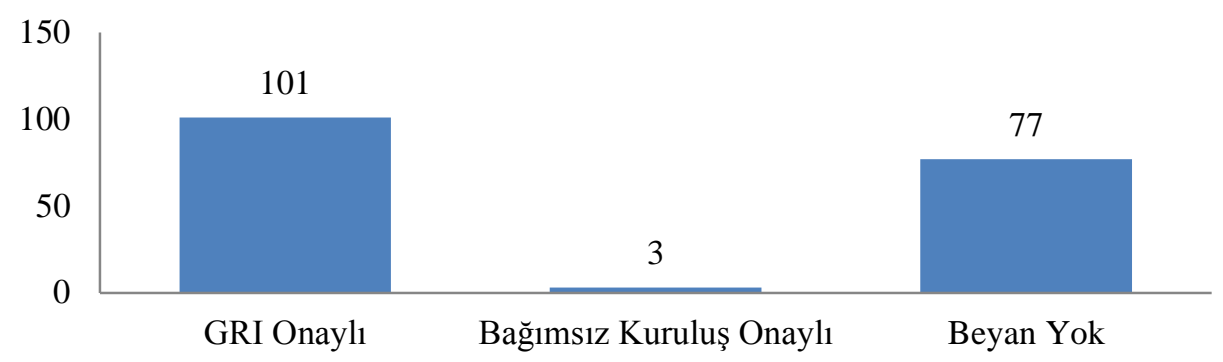

Araştırma kapsamındaki raporların GRI uygulama beyanına göre dağılımı Grafik 16'da gösterilmiştir. Buna göre GRI onaylı 101 ve bağımsız kuruluş onaylı 3 rapor yayınlanmıştır. Ayrıca GRI uygulama beyanı 73 rapor da ise beyan edilmemiştir. 


\section{Grafik 17: Referans/İnisiyatif}

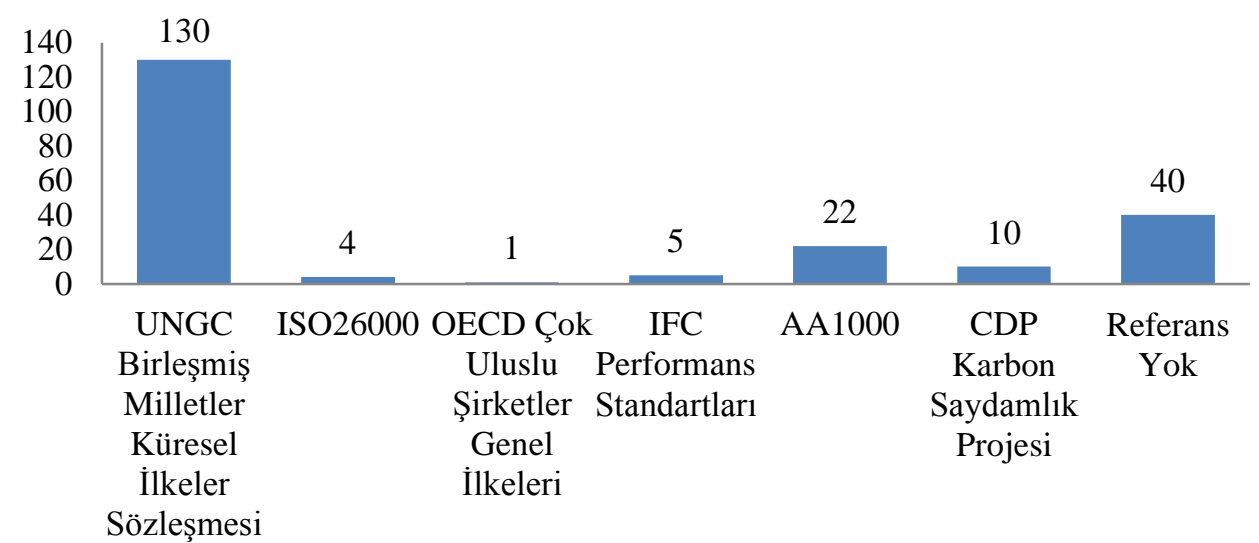

Araştırma kapsamındaki raporların referanslarına/inisiyatiflerine göre dağılımı Grafik 17'de gösterilmiştir. Kurumsal sürdürülebilirlik raporları tek bir referansı temel alabilirken, birden fazla referansı da temel olarak alıp uygulayabilmektedir. Buna göre 130 rapor UNGC Birleşmiş Milletler Küresel illkeler Sözleşmesi'ni temel almıştır. 40 raporda referans belirtilmemiştir. Diğerleri ise sırasıyla, 22 rapor AA1000'i, 10 rapor CDP Karbon Saydamlık Projesi'ni, 5 rapor IFC Performans Standartları'nı, 4 rapor ISO26000'i ve 1 rapor ise OECD Çok Uluslu Şirketler Genel IIlkeleri'ni temel alarak hazırlanmıştır.

\section{Grafik 18: Bağımsız Denetimden Geçme}

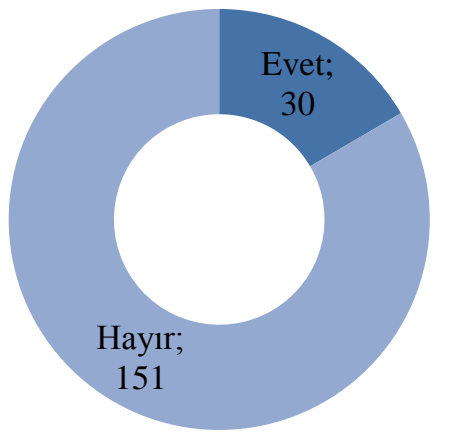

Araştırma kapsamındaki raporların bağımsız denetimden geçme durumuna göre dağılımı Grafik 18'de gösterilmiştir. Buna göre 151 rapor bağımsız denetimden geçmemiş; 30 rapor ise bağımsız denetimden geçmiştir. 


\section{Grafik 19: Denetim Sağlayıcısı}

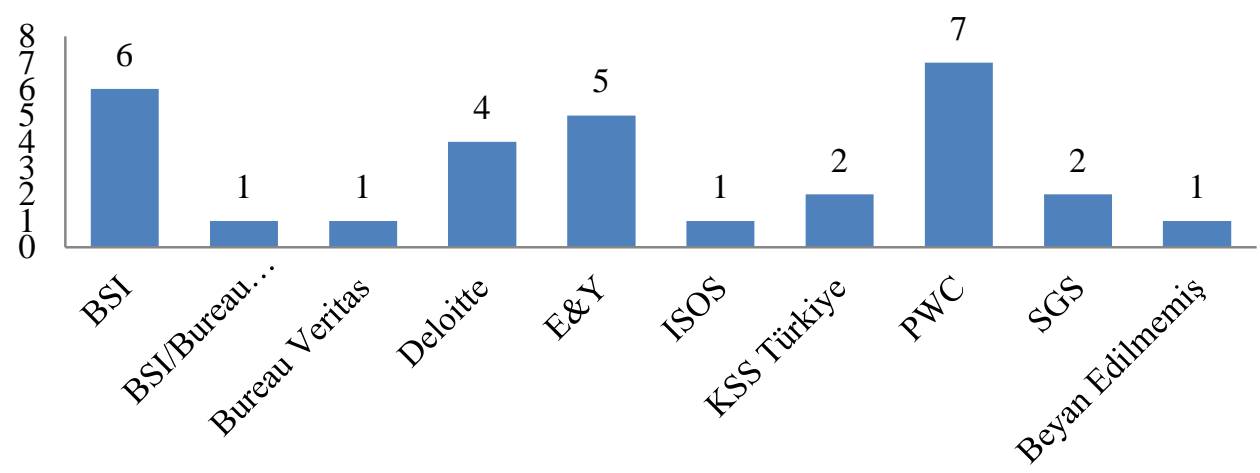

Araştırma kapsamındaki bağımsız denetimden geçmiş raporların denetim sağlayıcısına göre dağılımı Grafik 19'da gösterilmiştir. Bağımsız denetimden geçen 30 raporun, 6'sı BSI, 1'i BSI/Bureau Veritas, 1'i Bureau Veritas, 4'ü Deloitte, 5’i E\&Y, 1'i ISOS, 2'si KSS Türkiye, 7'si PWC, 2'si SGS tarafından denetlenmiştir. Ayrıca 1 raporun denetim şirketi ise beyan edilmemiştir.

\section{Grafik 20: Sektör Eklentisi}

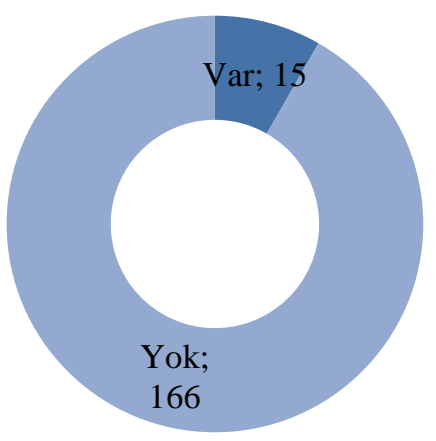

Araştırma kapsamındaki raporların sektör eklentisinin olup olmama durumuna göre dağılımı Grafik 20'de gösterilmiştir. Buna göre 166 raporda sektör eklentisi yokken; 15 raporda sektör eklentisi vardır.

\section{Grafik 21: Paydaş Paneli/Uzman Görüşü}

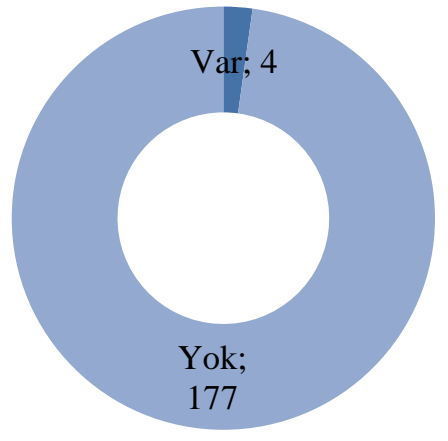

Araştırma kapsamındaki raporların paydaş paneli/uzman görüşü olup olmama durumuna göre dağılımı Grafik 21'de gösterilmiştir. Buna göre 177 raporda paydaş paneli/uzman görüşüne yer verilmezken; 4 raporda paydaş paneli/uzman görüşüne yer verilmiştir. 


\section{SONUÇ VE ÖNERILER}

Kurumsal sürdürülebilirlik raporlaması üzerine yapılan bu çalışmada, toplam 26 adet ölçüte yer verilmiştir. Bu ölçütler, rapor yayınlayan kuruluşlar ve raporlar olmak üzere iki grup altında toplanmıştır:

Son yıllarda kurumsal sürdürülebilirlik raporları aracılığıyla faaliyetlerinin ekonomik, çevresel ve sosyal boyutunu kamuoyuna açıklamayı tercih eden kuruluş sayısı artmaktadır. Mayıs 2015 itibariyle, 1999-2015 yılları arasında dünyada 7.547 kuruluş, 24.405 sürdürülebilirlik raporu yayınlamış ve bu raporların 18.743'ü ise GRI raporudur (08.05.2015 http://database.globalreporting.org). Türkiye'de ise 2005-2014 yılları arasında toplam 72 kuruluş, 181 adet rapor yayınlamıştır (01.05.2015). Bu raporların 130'u GRI raporlama rehberini temel almıştır. Bu rakamlardan anlaşılacağı üzere yıllar itibariyle yayınlanan sürdürülebilirlik raporlarının sayısının arttığı ve her geçen gün sürdürülebilirlik anlayışının daha fazla kuruluş tarafından dikkate alındığı görülmektedir.

Sürdürülebilirlik rapor türü olarak GRI'nın tercih edilme sebepleri olarak ise, çok uluslu şirketlerin yanı sıra küçük ve orta ölçekli işletmelerin de uygulayabileceği bir kılavuz olması, farklı dillere tercüme edilmiş olması, devlet ve yatırımcılar gibi paydaşlar tarafından kabul edilmiş olması, diğer raporlama çerçevelerini göz önünde bulundurarak hazırlanmış olması ve kullanımının kolay olması sıralanabilir.

Türkiye'de en çok imalat sektöründeki kuruluşların sürdürülebilirlik raporu yayınladığı görülmektedir. Buna göre imalat sektöründe faaliyet gösteren 27 kuruluş, toplamda 67 sürdürülebilirlik raporu yayınlamışlardır. Ayrıca imalat sektörünün sürdürülebilirlik raporları da niteliksel olarak incelenebilir ve böylece sürdürülebilirliğe ne derece önem verildiği belirlenebilir.

Bu çalışmada, raporlar sadece niceliksel açıdan ele alınmıştır. Bu raporların niteliksel açıdan incelenmesi de faydalı olabilir. Böylece raporların işlevselliğine dair bilgi edinilebilir.

\section{KAYNAKÇA}

Bansal, P. (2005). Evolving Sustainably: A Longitudinal Study of Corporate Sustainable Development, Strategic Management Journal, 26, s.197-218.

Borsa İstanbul (2014). Şirketler İçin Sürdürülebilirlik Rehberi, İstanbul.

Clikeman, P. M. (2004). Socially Conscious Corporation, Strategic Finance, April, s.22-27.

Dünya Çevre ve Kalkınma Komisyonu (1987). Ortak Geleceğimiz. İngiltere, Oxford: Oxford University Press.

Dyllick, T. ve Hockerts, K. (2002). Beyond The Business Case for Corporate Sustainability, Business Strategy and The Environment, 11 (2), s.130-142.

English, D., M., ve Schooley, D., K. (2014). The Evolution of Sustainability Reporting, The CPA Journal, March, s.2635.

GRI,https://www.globalreporting.org/languages/Turkish/Pages/S\%C3\%BCrd\%C3\%BCr\%C3\%BClebilirlikRaporlamas\%C4\%B1.aspx (Erişim Tarihi: 25.03.2015).

Herzig, C. and Schaltegger, S. (2006). Reporting External Accounting Frameworks and Benchmarking: Corporate Sustainability Reporting. An Overwiev. Sustainability Accounting and Reporting. (Ed: S. Schaltegger, M. Bennet and R. Burrit). Netherlands, Dordrecht: Springer, s.301-324. 
Schaltegger, S., Bennet, M. ve Burrit, R. (2006). Sustainability Accounting and Reporting: Development Linkages and Reflection. An Introduction. Sustainability Accounting and Reporting. (Ed: S. Schaltegger, M. Bennet and R. Burrit). Netherlands, Dordrecht: Springer, s.1-35.

Sustainability Disclosure Database, http://database.globalreporting.org erişim tarihi: 08.05.2015.

Tokgöz, N. ve Önce, S. (2009). Şirket Sürdürülebilirliği: Geleneksel Yönetim Anlayışına Alternatif, Afyon Kocatepe Üniversitesi i. i. B. F. Dergisi, 11 (1), s.249-275.

Türkiye'nin Sürdürülebilirlik Portalı, www.kurumsalsurdurulebilirlik.com erişim tarihi: 01.05.2015.

Wilson M. (2003). Corporate Sustainability: What is it and where does it come from?, Ivey Business Journal, March-April, s.1-5.

Zink, J. K., Steimle, U., Klaus F. (2008). Human Factors, Business Excellence And Corporate Sustainability: Differing Perspectives, Joint Objectives. Corporate Sustainability as a Challenge For Comprehensive Management. (Ed: K. J. Zink). Almanya, Heidelberg: Phsica-Verlag. 1-18.

Ek: Sürdürülebilirlik Raporu Yayınlayan Kuruluşlar ve Sektörleri

\begin{tabular}{|c|c|c|}
\hline imalat & Bilgi ve Iletișim & inşaat \\
\hline Abdi İbrahim & Avea & Akçansa \\
\hline Akkim & İndeks İletişim & Çimsa \\
\hline Aksa Akrilik & Koç Sistem & Doğuş İnşaat \\
\hline Anadolu Efes & N’PR İletişim Danışmanlığı & \\
\hline Arçelik & Turkcell & Kamu Yönetimi ve Savunma \\
\hline Bilim İlaç & Vodafone Türkiye & Aselsan \\
\hline CMS & Elektrik, Gaz, Buhar & IETT \\
\hline Coca-Cola İçecek & Akenerji & Nilüfer Belediyesi \\
\hline Doğuş Otomotiv & Aygaz & \\
\hline Erdemir & Bursagaz & Ulaștırma ve Depolama \\
\hline İçdaş & OPET & Havaş \\
\hline Mc Donalds Türkiye & Tüpraş & Mars Logistics \\
\hline Memteks & Zorlu Enerji & TAV \\
\hline Milteks & Finans ve Sigorta Faaliyetleri & Diğer \\
\hline Mustafa Nevzat & Akbank & Brisa \\
\hline Orta Anadolu & Garanti Bankası & ISS Türkiye \\
\hline Otokar & Şekerbank & Şişecam \\
\hline Pharmavision & TSKB & Steppen \\
\hline Roche Türkiye & Türkiye Finans & Türkiye IMSAD \\
\hline Sandoz Türkiye & Türkiye İş Bankası & \\
\hline Sanofi Türkiye & Yapı Kredi & \\
\hline Santa Farma & Ziraat Bankası & \\
\hline SLN Tekstil & Eğitim & \\
\hline Tofaş & Kadir Has Üniversitesi & \\
\hline Tübaş & & \\
\hline
\end{tabular}

